\title{
Challenges and sustainability of wheat production in a Levantine breadbasket: The case of the West Bekaa, Lebanon
}

\author{
Salwa Tohmé Tawk ${ }^{\text {** }}$ \\ Lebanese University and American University of Beirut
}

\author{
Mabelle Chedid, ${ }^{\mathrm{b}}$ Ali Chalak, ${ }^{\mathrm{c}}$ Sarah Karam, ${ }^{\mathrm{b}}$ and Shadi Kamal Hamadeh ${ }^{\mathrm{b}}$ \\ American University of Beirut
}

\begin{abstract}
Submitted June 17, 2018 / Revised November 4 and D ecember 14, 2018, and January 4, 2019 /
Accepted January 4, 2019 / Revised January 14, 2019 / Published online April 3, 2019

Citation: Tohmé Tawk, S., Chedid, M., Chalak, A., Karam, S., \& Hamadeh, S. K. (2019). Challenges

and sustainability of wheat production in a Levantine breadbasket: The case of the West Bekaa,

Lebanon. Journal of A griculture, F ood Systems, and C ommunity D evelopment, 8(4), 193-209.

https:/ / doi.org/ 10.5304/ jafscd.2019.084.011
\end{abstract}

Copyright ( 2019 by the Authors. Published by the Lyson Center for Civic Agriculture and Food Systems. Open access under CC-BY license.

\begin{abstract}
The farming sector in Lebanon, particularly grains production, is threatened by environmental, socioeconomic, and political factors that have led to a high dependence on food imports, thereby undermining national food security. This study focuses on wheat production in its natural Mediterranean habitat (the Levant) and its sustainability in the West Bekaa through value chain analysis that aims

a* Corresponding author: Salwa Tohmé Tawk, Associate Professor, Faculty of Agronomy, Lebanese University, BP 55484, D ekwaneh, Beirut, Lebanon; and member of the Environment and Sustainable D evelopment Unit, Faculty of Agriculture and Food Sciences, American University of Beirut, Beirut, Lebanon; salwatawk@ gmail.com

$\mathrm{b}$ Environment and Sustainable D evelopment Unit, Faculty of Agriculture and Food Sciences, American University of Beirut, Beirut, Lebanon.

c D epartment of Agriculture, Faculty of Agriculture and Food Sciences, American University of Beirut, Beirut, Lebanon.
\end{abstract}

to identify constraints and opportunities in the production system. The analysis is based on a survey at the level of the producers to identify the planted wheat varieties, wheat production systems, land tenure systems, marketing channels, socioeconomic factors of farmers, and different types of wheat by-products. This study reveals important challenges facing the sustainability of wheat production, including farmers resorting to hybrid

\section{Funding Disclosure}

The authors gratefully acknowledge the Lebanese National Council for Scientific Research for providing funding for this study under their grant research program.

\section{Authors' Contributions}

S. T. T. and S. H. designed the study. A. C. designed the sampling method and analyzed the data statistically. S. T. T. and M. C. analyzed the data and wrote the manuscript. A. C. and S. H. contributed in improving the data analysis and discussion sections. S. K. contributed in improving the manuscript. 
wheat varieties, the dependence of farmers on wheat subsidies as an incentive, the lack of land tenure security, and the virtual absence of wellorganized cooperatives. On the other hand, our evidence suggests a strong dependence among wheat farmers on integrated production systems that promote agricultural sustainability. We conclude this report with recommendations to secure the sustainability of wheat production in West Bekaa in particular, and in Lebanon in general.

\section{Keywords}

Farming Systems, Levant, Lebanon, Subsidy, Sustainability, Wheat

\section{Introduction}

Sustainable F ood Production Our food system has become highly globalized and industrialized, and the way our food is produced, distributed, and consumed has become unsustainable. This has thus contributed to unsustainable economies, environmental damage, and health problems (Caraher, Dixon, Lang, \& Carr-Hill, 1999). In response to such constraints, localism has been proposed as a form of resistance against the homogenizing effects of globalization (G ottlieb \& Joseph, 1997), and locally based food systems have become indispensable for attaining sustainable agriculture and food security (Allen, 2010).

Local food systems (LFS) are those in which the production, processing, trading, and consumption of food are integrated to promote the environmental, economic, social, and nutritional health of a specific geographic area (Fisher, 1997). That being said, understanding the production value chains of crops, which is the primary aim of this study, can aid in the promotion of LFS by facilitating the identification of leverage points to effectively valorize local products and support local farmers.
The Near East, an area characterized by a rich topographical diversity with an abundance of contrasting and changing environments, is home to both rich plant diversity and rich cultural innovations (McCorriston \& Hole, 1991). It is one of the regions where numerous types of temperate-zone agriculture originated 10,000 years ago and where wild relatives and landraces ${ }^{1}$ of enormous genetic diversity can still be found (McCorriston \& Hole, 1991). Cereal culture, including cultivated strains of wheat and barley, originated in the Levant ${ }^{2}$ and expanded northward from its natural Mediterranean habitats into central Europe in the $6^{\text {th }}$ millennium B.C (Kislev, 1984). It traversed from the Fertile Crescent through northern Iran to central Asia, and westward to Europe through southwestern Anatolia (Quitta, 1971), and it expanded to the islands of Cyprus, Crete, and Malta in the 6th and 5th millennia B.C. (Follieri, 1973). However, the genetic diversity of many of the major crops and forage species in this region is threatened (Chalak \& Sabra, 2015). In Lebanon, several wild relatives and landraces of important crops, including wheat, barley, food and forage legumes, and fruits trees, have been reported (Chalak \& Sabra, 2015). Their conservation is crucial to sustain agricultural biodiversity and food security at the local and global level, as well as to sustain the livelihoods of local communities which are the main guardians of valuable agrobiodiversity (Anderson, 2003; Assi, 2005). In addition, these wild relatives and landraces are some of the main ingredients in a wide variety of traditional Lebanese processed foods, such as kishk (made of durum wheat and milk from local breed goats), shankleesh (a yogurtbased cheese), dibs el roumman (pomegranate molasses), dried fruits (figs, cherries, etc.), and edible wild plants commonly used in traditional cuisine. Investing in research that contributes to sustaining these landraces is therefore crucial to secure Lebanese culinary heritage, food security,

\footnotetext{
${ }^{1} \mathrm{~A}$ landrace is "a dynamic population(s) of a cultivated plant that has historical origin, distinct identity and lacks formal crop improvement, as well as often being genetically diverse, locally adapted and associated with traditional farming systems" (Camacho Villa, Maxted, Scholten, \& Ford-Lloyd, 2005, p. 373.

2 The Levant is considered to be part of southwestern Asia; it ranges from the southern borders of the Taurus Mountains in Turkey into the Sinai Peninsula. Its eastern border comprises the Middle Euphrates Valley, Palmyra basin, Gebel ed-D ruz, and Azraq, as well as the El-Jafr basins (Bar-Y osef \& Belfer-Cohen, 1989).
} 
and farmers' livelihoods.

The sustainability of a certain product is assessed using three main criteria: environmental, social, and economic sustainability (O hlsson, 2014). The social aspect of sustainable production addresses human rights, access to assets, and working conditions. The economic aspect considers a sustainable return on investment. Lastly, the environmental aspect involves the contribution to climate change and loss of diversity (O hlsson, 2014). For the purpose of assessing the sustainability of wheat production in West Bekaa, this study examines the cultivated wheat varieties, production systems, and cultural practices adopted by farmers that affect environmental health. Additionally, this study explores the land tenure systems, marketing strategies, and socio-economic factors reflecting the socio-economic status of farmers who play a significant role in ensuring wheat sustainability. Finally, the study examines wheat by-products to highlight the importance of sustaining wheat for the conservation of Lebanese culinary heritage.

Wheat Production Wheat is a dominant staple grain, providing up to one third of the calories consumed in the Middle East and North Africa (MENA) region (World Bank, 2009). Although this region is the largest net importer of wheat in the world, wheat is the largest field crop by area in the region by far and is currently cultivated on about 26 million hectares (64 million acres) (A hmed, Hamrick, G uinn, Abdulsamad, \& Gereffi, 2013; Nigatu \& Motamed, 2015). This area is expected to increase by about $0.4 \%$ annually through 2024 (Nigatu \& Motamed, 2015).

Wheat plays an important role in the Lebanese diet and is used, depending on the variety, to make different types of borghol (cracked wheat), kishk (cracked wheat fermented in yogurt), and flour (for saj bread). The total yearly consumption of wheat in Lebanon ranges between 400,000 to 450,000 tons (Harrigan, 2014), of which only about 130,000 tons are locally produced, and the rest imported (Food and Agriculture 0 rganization of the United Nations [FAO ], 2018). The region of Bekaa (Central and West) yields the highest production of wheat ( $44 \%$ of the national total), followed by Baalbeck and Hermel (14\%). Zero percent of production is reported in Mount Lebanon (Ministry of Agriculture $[\mathrm{MoA}]$ \& FAO , 2012). Farmers identify landraces of wheat morphologically and by their culinary use. Farmers typically give these landraces local names that differ between regions. However, no research has investigated the in-situ preservation of wheat landraces and related it to the sustainability of the wheat production value chain.

On the basis of the above-mentioned lack of research, this research analyzes the production value chain of the locally produced wheat and its sustainability.

\section{Methodology}

This research surveys and evaluates wheat production and processing in West Bekaa. The methodology relies on the value chain analysis (Hellin \& Meijer, 2006; Tohmé Tawk, Moussa, Hamadeh, \&Abi Saiid, 2011; Tohmé Tawk, Abi Saiid, \& Hamadeh, 2014) of wheat production, which includes a description of the agricultural practices used, the wheat varieties grown, and the marketing channels used by farmers. This value chain analysis reveals different constraints and opportunities in the production system, resulting in the assessment of its sustainability. Wheat varieties were identified based on the local terminology. However, it is worth noting that these varietal names might differ from one region to another and are not accurate indicators of the varieties; only D NA tests, which were not within the scope of this study, can help when comparing varieties.

Survey Procedure

A survey was conducted during the summer of 2014 in the West Bekaa, a region known for wheat farming and processing of wheat by-products. A semistructured questionnaire that asked both openended and closed-ended questions was developed and comprised sections: (1) Screening questions, (2) Questions of adopted farming practices and farmer's knowledge, (3) Questions on the social sustainability, (4) Economic sustainability, (5) Socio-demographic questions, and (6) Wheat byproducts. The questions related to the sustainability of wheat were adapted from the sustainability 
indicators of the French model IDEA, Indicateur de Durabilité des Exploitations Agricoles (Zahm, Viaux, Vilain, Girardin, \& Mouchet, 2008).

A total of 63 farmers from the West Bekaa were interviewed. All producers were selected by means of snowball or chain sampling since they are sparsely distributed in the regions and no official registers are available for them to provide a sampling framework. It was difficult to achieve an accurate representative sample in the absence of any statistical data; however, respondents were selected in a way to achieve broad geographical coverage of the targeted region in order to avoid any selectivity bias. Wheat producers representing small and large-scale farms, ranging between 2 and 3000 dunums (0.2-300 ha or 0.5-740 acres), were selected with the help of local key informants. O ut of the 63 respondents, 54 answered the tenancy question on whether they own or rent the land. Therefore, the nine who did not answer this question were dropped from the final sample used for analysis because this tenure data was essential to understand the wheat value chain. Collected quantitative and qualitative data were analyzed using STATA version 12.

\section{Results}

The survey's results reveal that wheat is still a crop commonly planted in the West Bekaa on farms between 0.2 and 300 ha (0.5-740 acres) in size.

\section{E nvironmental Sustainability}

Cultivated wheat varieties

The names farmers use for wheat differ among regions and are not accurate indicators of the wheat varieties. Local wheat is specified as Baladi (local), Bekaii (referring to the Bekaa region), Asmar (brown wheat), Salamouneh (having elongated form), Howraneh (referring to the volcanic plateau Hawran in Syria), Ahmar (brown), Biyadi (white). Most traditional by-products- namely bulgur, kishk, and flour for traditional saj flat bread-are produced using these local varieties. D urum wheat (kasi) and soft wheat (tareh) are also planted.

Farmers are offered improved wheat variety seeds from the Lebanese Agricultural Research
Institute (LARI) at subsidized prices (LARI \& MoA, 2014). Based on the survey, 55\% of producers in West Bekaa get their wheat seeds from LARI; the others buy their seeds from commercial agricultural suppliers in the area. The main varieties available at LARI (used by 18 producers) are called Miki, Lahen 2, and Lahen 3 (LARI \& MoA, 2014), and Masara, introduced in 2000. Farmers also mentioned other names of wheat varieties provided by LARI: Saragolla and Italian. The varieties bought from commercial suppliers are Shem 1, Shem 2, and Shem 3. All producers mentioned that the hybrid varieties from LARI and commercial suppliers have higher yields than landraces and that landraces are rarely used due to their low yield.

W heat production

Wheat production systems. As defined by Madry et al. (2013), homogeneous farms are classified as one group or type of farm, representing a single farming or production system. In order to identify the different wheat-based production farms, we developed a typology based on selected criteria related to the crop sequence and the integration of other agricultural activities, such as crops and animal production. Five wheat-based production systems were identified:

1. Wheat-fallow (17\%): Wheat monoculture system where only wheat is produced, and the land is kept fallow after harvest;

2. Rotation of wheat and annuals (42\%): This is the prevailing system where wheat production is part of a crop rotation involving other annual crops, mainly chickpeas, potato, and other vegetables (tomato, cucumber, pepper, zucchini, etc.);

3. Integrated wheat-livestock systems (8\%): Integrated livestock-wheat production system where only wheat is grown on the land and livestock production, mainly cow and/ or small ruminants, is integrated with it;

4. Integrated crop-livestock systems (33\%) including 2 subsystems:

a. Rotation of wheat with annuals combined with animal production (25\%): Integrated crop-livestock system where wheat is combined with other annual 
crops, such as pulses or vegetables and animal production;

b. Rotation of wheat with annuals combined with perennial crops and animal production (8\%): Integrated crop-livestock system where wheat is combined with annuals and orchards (fruit trees such as olives, apples, almonds, and vineyards), as well as animal production.

Wheat production combined with animal production (Types 3 and 4) represents $41 \%$ of the sample in West Bekaa (Figure 1). Sheep and goat herds of the West Bekaa leave the mountain rangelands by mid-summer and migrate toward the plain to feed on crop residues (wheat and vegetables). Farmers who do not own animals lease their land to shepherds for an average fee of $3000 \mathrm{LBP} / \mathrm{dn}$ (about US $\$ 2 / 0.1 \mathrm{ha}$ ) (US $\$ 1=1,500$ LBP; 1 dn [dunum] $=0.1$ hectare $=0.25$ acre) of wheat residues and $6000 \mathrm{LBP} / \mathrm{dn}$ (about US $\$ 4 / 0.1$ ha) of vegetable residues. From this arrangement, producers benefit from the organic matter left in the form of animal manure, which improves soil fertility. These results show the close links between wheat production and animal-keeping, thereby contributing to each other's sustainability.

According to the results we obtained, the average area of wheat cultivation is $297 \mathrm{dn}$ (30 ha or 73 acres) ranging between as low as $2 \mathrm{dn}(0.2$ ha or 0.5 acre) up to $3000 \mathrm{dn}$ (300 ha or acres 740 acres).
The average wheat yield is $458 \mathrm{~kg} / \mathrm{dn}(4580 \mathrm{~kg} / \mathrm{ha}$ or 4,076 lbs./ acre), ranging between $100 \mathrm{~kg} / \mathrm{dn}$ (1000 kg/ ha or 890 lbs./ acre) and 800 kg/ dn (8000 $\mathrm{kg} / \mathrm{ha}$ or 7,120 lbs./ acre), exceeding the average of $300 \mathrm{~kg} / \mathrm{dn}$ (3000 kg/ ha or 2,670 lbs./ acre) reported in the latest national census (MOA \& FAO , 2012).

Cultural practices. Sixty-two percent of the farmers irrigate once or twice and the rest irrigate 3 or 4 times. The plowing frequency varies between 1 and 3 times, depending on soil quality and the production system. Ninety-two percent of the farmers apply herbicides once per season; the remaining $8 \%$ do not apply herbicide. Farmers apply urea (43\% nitrogen) once, at a rate of minimum 12 $\mathrm{kg} / \mathrm{dn}$ (120 kg/ ha or $107 \mathrm{lbs} . /$ acre) to maximum $80 \mathrm{~kg} / \mathrm{dn}(800 \mathrm{~kg} / \mathrm{ha}$ or $712 \mathrm{lbs} . / \mathrm{acre})(33.6 \mathrm{~kg}$ of net $\mathrm{N} / \mathrm{dn} /$ season [336 $\mathrm{kg}$ of net N/ ha/ season or 299 lbs. of net N/ acre/ season]). Fifty-nine percent

Table 1. Wheat Producers vs. Land Tenure and Land Dedicated to Wheat Production

\begin{tabular}{|c|c|c|c|c|c|c|c|c|}
\hline \multirow[b]{3}{*}{ Land Tenure } & \multicolumn{6}{|c|}{ Land dedicated to wheat production (\%) } & & \\
\hline & \multicolumn{2}{|c|}{ Part of the land } & \multicolumn{2}{|c|}{ All of the land } & \multicolumn{2}{|c|}{$\begin{array}{l}\text { Do not follow the same } \\
\text { system every year }\end{array}$} & \multicolumn{2}{|c|}{ Total } \\
\hline & Frequency & $\%$ & Frequency & $\%$ & Frequency & $\%$ & Frequency & $\%$ \\
\hline Owner & 7 & 35 & 1 & 3 & 5 & 83 & 13 & 24 \\
\hline Tenant & 13 & 65 & 24 & 86 & 1 & 17 & 38 & 70 \\
\hline Owner-Tenant & 0 & 0 & 3 & 11 & 0 & 0 & 3 & 6 \\
\hline Total & 20 & 100 & 28 & 100 & 6 & 100 & 54 & 100 \\
\hline
\end{tabular}


Table 2. Land Tenure Versus Cropping System

\begin{tabular}{|c|c|c|c|c|c|c|c|c|}
\hline \multirow[b]{3}{*}{ Land Tenure } & \multicolumn{6}{|c|}{ Cropping System } & & \\
\hline & \multicolumn{2}{|c|}{ Wheat-fallow } & \multicolumn{2}{|c|}{ Wheat-annuals } & \multicolumn{2}{|c|}{$\begin{array}{l}\text { Integrated crop system } \\
\text { (wheat; annual; animal) }\end{array}$} & \multicolumn{2}{|c|}{ Total } \\
\hline & Frequency & $\%$ & Frequency & $\%$ & Frequency & $\%$ & Frequency & $\%$ \\
\hline At least part-owner & 0 & 0 & 3 & 15 & 8 & 40 & 11 & 23 \\
\hline Tenant & 8 & 100 & 17 & 85 & 12 & 60 & 37 & 77 \\
\hline Total & 8 & 100 & 20 & 100 & 20 & 100 & 48 & 100 \\
\hline
\end{tabular}

Fisher's exact test $p$ value is 0.000 .

Table 3. Type of Marketing Channels Versus Land Tenure

\begin{tabular}{|c|c|c|c|c|c|c|c|c|}
\hline \multirow[b]{3}{*}{ Type of market } & \multicolumn{6}{|c|}{ Land Tenure } & & \\
\hline & \multicolumn{2}{|c|}{ Owner } & \multicolumn{2}{|c|}{ Tenant } & \multicolumn{2}{|c|}{ Owner-Tenant } & \multicolumn{2}{|c|}{ Total } \\
\hline & Frequency & $\%$ & Frequency & $\%$ & Frequency & $\%$ & Frequency & $\%$ \\
\hline Sold to state & 2 & 29 & 29 & 88 & 2 & 67 & 33 & 77 \\
\hline Direct sales & 1 & 14 & 0 & 0 & 1 & 33 & 2 & 5 \\
\hline $\begin{array}{l}\text { Sales through a } \\
\text { dealer }\end{array}$ & 4 & 57 & 4 & 12 & 0 & 0 & 8 & 18 \\
\hline Total & 7 & 100 & 33 & 100 & 3 & 100 & 43 & 100 \\
\hline
\end{tabular}

Table 4. Type of Marketing Channels Versus Mean Cultivated Area in Dunums

\begin{tabular}{lc}
\hline Type of market & Mean (cultivated area in dn | ha | acre) \\
\hline Sold to state & $375|37.5| 93$ \\
\hline Direct sales & $205|20.5| 51$ \\
\hline Sales through a dealer & $148|14.8| 37$ \\
\hline
\end{tabular}

of the producers do not use pesticides, whereas the remaining $41 \%$ spray 1 to 2 applications, which is not intensive compared to the amount used for vegetable production. In addition, $95 \%$ of producers do not apply manure.

\section{Socio-E onomic Sustainability}

L and tenure systems

In the West Bekaa, most of the wheat producers are tenants (70\%), and almost $86 \%$ of those produce only wheat on the land. O wners represent $24 \%$ of producers and tend to grow wheat on just part of their land. Based on the survey results, the remaining land is cultivated with perennial crops such as fruit trees (cherries, apples, grapes, olives, and almonds). Few producers (6\%) are tenants and owners simultaneously and tend to cultivate only wheat. O wner-tenants are farmers who own part of their tended land and rent additional land. In addition, 6 producers reported that they do not follow a regular system every year (Table 1). Land tenure is not significantly correlated with the size of the farm.

A Fisher's exact test looked into the potential relationship between land tenure and cropping system. Farmers that are owners on all or part of their tended lands are grouped into one category, "at least part owner" (Table 2). Results show that integrated crop system farmers (i.e., farmers who combine animal production with wheat and possibly annuals) are significantly less likely to be tenants than either wheat-fallow or wheat-annuals farmers ( $p$ value $=0.000$ ). This is somewhat expected, as integrated cropping systems are more demanding in terms of investment and have potentially longer return periods than either of the other two systems; therefore, they would require more secure access to land. The results come from 48 respondents, as 6 out of 54 did not answer this question.

M ark eting strategies

Most wheat growers (94\%) produce wheat for 
Journal of Agriculture, Food Systems, and Community D evelopment

ISSN: 2152-0801 online

https:/ / www.foodsystemsjournal.org

Table 5. Number of Household Income Earning Members and Agriculture as Only Source of Revenue

\begin{tabular}{|c|c|c|c|c|c|c|c|c|}
\hline \multirow{3}{*}{$\begin{array}{l}\text { Agriculture as the only } \\
\text { source of revenue }\end{array}$} & \multicolumn{6}{|c|}{ Number of income-earning household members } & & \\
\hline & \multicolumn{2}{|c|}{1 member } & \multicolumn{2}{|c|}{2 members } & \multicolumn{2}{|c|}{3 or more } & \multicolumn{2}{|c|}{ Total } \\
\hline & Frequency & $\%$ & Frequency & $\%$ & Frequency & $\%$ & Frequency & $\%$ \\
\hline Yes & 7 & 37 & 2 & 14 & 1 & 11 & 10 & 24 \\
\hline No & 12 & 63 & 12 & 86 & 8 & 89 & 32 & 76 \\
\hline Total & 19 & 100 & 14 & 100 & 9 & 100 & 42 & 100 \\
\hline
\end{tabular}

Fisher's exact test $p$ value is 0.258

Table 6. Agriculture as the Only Source of Revenue With Respect to Total Surface of Area Cultivated

\begin{tabular}{lccc}
\hline $\begin{array}{l}\text { Agriculture as the only } \\
\text { source of revenue }\end{array}$ & Frequency & $\begin{array}{l}\text { Total Surface Area } \\
\text { cultivated (Mean) (dn) }\end{array}$ & \begin{tabular}{c} 
Standard deviation \\
\hline Yes
\end{tabular} \\
\hline No & 35 & 169.1 & 197.1 \\
\hline
\end{tabular}

Wilcoxon rank-sum test $p$ value is 0.48

commercial purposes. Almost half market more than $50 \%$ of the yield, while the other half sells their entire yield. The marketing channels vary according to the land tenure system adopted by the farmer (Table 3) whereby tenants tend to sell to the state more than to owners. The results are from 43 respondents, as 11 out of 54 did not answer this question.

Moreover, when looking at the type of marketing versus the mean cultivated area, we found that the producers with the largest areas tend to sell to the state (Table 4). This is likely because the payment is delayed for few months after the harvest, and only large-scale or well-capitalized farmers can sustain themselves without relying on immediate cash. Hence, small-scale farmers tend to sell to dealers or traders at lower prices (sometimes at only a third of the state price) in order to receive payment quickly and before the quality of the product deteriorates.

In addition, most farmers are not organized in cooperatives. Only 15\% are members of an agricultural cooperative, and not necessarily a wheat production cooperative.

Socio-economic F actors

Age. Our results show that the majority of farmers are older than 40 years of age: $52 \%$ are older than
$60,40 \%$ are between 40 and 59 years of age, and only $8 \%$ are younger than 40 .

\section{Agriculture as the only source of revenue.}

Twenty-four percent of interviewed wheat producers rely on agriculture as their only source of revenue. The contribution of family members to the household income (Table 5) reveals that when the farmer (head of the family) specializes in agriculture, there are fewer household members involved in other economic activities. However, Fisher's exact test returns a p value of 0.258 , indicating that the above trend is not significant. Note that these results pertain to 42 respondents out of 54 for either of the two questions "number of household members" and "agriculture as the only source of revenue" as the nonrespondents may have judged the information to be personal and confidential.

Furthermore, we looked at how agriculture as the only source of income relates to the total surface area cultivated by the farmer. Table 6 shows that, on average, a farmer who relies solely on agriculture for income cultivates a smaller surface area than a farmer who does not. O ne can speculate that full-time farmers as a category tend to be smaller. This said, a two-sample Wilcoxon rank-sum (Mann-Whitney) test indicates that the difference between the two average surface areas is not significant $(\mathrm{p}=0.48)$.

Subsidy. The government of Lebanon assists local wheat farmers in the form of subsidies. The subsidy is handled by the $\mathrm{G}$ eneral Directorate of 
Cereals and Sugar Beet Subsidy (GD CS), which is under the jurisdiction of the Ministry of Economy and Trade. According to the GDCs, "The subsidy was designed to shield farmers from the fluctuations of international wheat prices" (Blominvest Bank, 2016, p. 5). The G DCS purchases the wheat from the farmers at a set price and then sells it at international market prices.

When producers were asked whether they would continue cultivating wheat if the government no longer subsidized the wheat production in Lebanon, about $42 \%$ of them answered that they might or definitely would stop growing wheat. Among all producers, only $9 \%$ responded that they would "definitely continue" growing it, and 17\% answered that they would "maybe continue" growing it (Table 7).

For the majority of surveyed farmers (75\%), wheat is planted is mainly for rotation purposes to rest the land. This means that wheat production is rotated with annuals and may also involve animal production. This is encouraged by the subsidy that compensates for part of the production cost.

By-products of wheat

Wheat by-products include bulgur and kishk. Bulgur is dry cracked wheat and is a traditional product heavily used in the Lebanese diet. Kishk is a traditional dairy product prepared with bulgur fermented in milk or yogurt. Among the wheat producers from the West Bekaa, 51\% do not process their wheat, while the remaining $49 \%$ transform it into kishk alone or bulgur alone, or both kishk and bulgur $(60 \%, 10 \%$, and $30 \%$, respectively).

Women are mainly involved in food processing activities rather than wheat production activities. In fact, nearly all of the surveyed wheat producers are males (98\%). However, females are involved in kishk processing.

\section{Bulgur production}

Our results show that bulgur is either purchased from mills or produced at the household level. Most of the processors used similar practices in the
Table 7. Decision Taken by Producers for Growing Wheat if Subsidy Is Stopped

\begin{tabular}{lcc}
\hline Decision of producer & Frequency & $\%$ \\
\hline Definitely continue growing & 4 & 9 \\
\hline May continue growing & 7 & 17 \\
\hline Hope will be able to continue growing & 11 & 26 \\
\hline Might stop growing & 9 & 21 \\
\hline Will definitely stop growing & 9 & 21 \\
\hline Will try growing in a year & 2 & 4 \\
\hline Don't know & 1 & 2 \\
\hline Total & 43 & 100
\end{tabular}

processing of bulgur. Of the producers, $69 \%$ process bulgur indoors, while the rest process it outdoors. Most of the producers (83\%) market less than $50 \%$ of their total bulgur and retain the rest for home consumption, as bulgur is a main ingredient in the traditional Lebanese cuisine.

Kishk production

Kishk is mainly produced by women. Kishk production is a major constituent of household traditional food preservation and diet. It is a traditional, artisanal product and is a family activity carried out at the household level and led by women. None of the producers is $100 \%$ commercial, since kishk is a traditional preserve for home consumption. Based on our data, the average production of kishk ranges between 5 to $500 \mathrm{~kg}$ (11 to 1,102 lbs.) per year per producer or group of producers.

\section{Discussion}

\section{E nvironmental Sustainability}

W heat varieties

The current study reveals the strong dependence of wheat farmers on improved wheat varieties. None of the identified farmers reported using local landraces. Further investigation and research are needed to identify producers using landraces, the origin of these seeds, and the reasons for continued use. Conserving the diversity of wild relatives has become a priority for promoting food security in the face of the devastating impacts of climate change. Crop wild relatives are adapted to a diverse 
range of habitats and hold genetically important traits, such as biotic and abiotic stress resistance, and thus able to enhance yield and production stability (FAO , 2008; G uarino \& Lobell, 2011; Maxted, Ford-Lloyd, Jury, Kell, \& Scholten., 2006; Vollbrecht \& Sigmon, 2005). Therefore, conserving wheat landraces is vital for the enhancement and stability of wheat production. Wheat landracesconsidered a reservoir of genes that plant breeders need in their wheat improvement programs-could be conserved through both ex situ and in situ preservation methods. ${ }^{3}$ Although ex situ holds potential for safeguarding genetic resources, it must be complemented by in situ conservation that maintains the evolutionary dynamics of the wild varieties (Esquinas-Alcázar, 2005). Acknowledging the roles of peasants, farmers, pastoralists, and their traditional knowledge is vital for conserving agrobiodiversity. In addition, if farmers lose access to their wild crop relatives, they lose control over their heritage, as well as have reduced potential for benefiting from sustainable and highly productive agricultural practices, which are both a cause and a consequence of biodiversity ( $\mathrm{G}$ rain, 1996). Therefore, considering in-situ preservation would ensure the conservation of precious genetic resources for future generations.

Few projects have been implemented to support in-situ conservation and sustainable use of biodiversity in Lebanon. Most studies follow the community-based approach and work with local communities, farmers, and NGOs with a focus on crops of global significance for food and agriculture (Tohmé Tawk et al., 2014). Assi (2005) conducted agro-ecological and eco-geographic studies, as well as socio-economic, indigenous knowledge, and botanical surveys in some rural villages and found the presence of several wild relatives of wheat, such as A egilops spp., Tritiaum dicoocoides, T. urartu, and T. boeticum species in two sites in the Bekaa Valley, Ham and Maarabon. These wild species are the ancestors of the currently used local landraces of durum wheat such as $\mathrm{H}$ ourani, Bek aii, Salamouni, D ouchani, and N abeljamal. However, as revealed by farmers in the current study, the hybrid varieties from LARI and commercial suppliers have higher yields than landraces, which are rarely used due to their low yield. Therefore, providing the right incentives for planting and conserving wheat landraces and considering in-situ conservation of wild crop varieties as a national priority hold significant potential for managing agrobiodiversity, preserving Lebanese cultural heritage, and enhancing food security.

\section{W heat production systems}

The current study reveals the close interaction between wheat production and animal husbandry, in which $41 \%$ of the farmers integrate the two production systems. According to the IDEA method, production systems combining crops and livestock are more sustainable than other systems (Zahm et al., 2008). A sustainable agricultural production system must address five main factors: (1) supplying consumers' needs, (2) preserving the environment through the stewardship of resources such as land and water, (3) using on-farm resources efficiently, (4) sustaining the economic viability of farmers, and (5) improving the quality of life for producers and society (Sassenrath et al., 2009; Walters et al., 2016). Integrated agricultural production techniques are one way to accomplish these sustainability goals. The integrated production system combines crop and livestock inputs and outputs to promote environmentally beneficial farming practices (Boller at al., 2004; Hendrickson, Hanson, Tanaka, \& Sassenrath, 2008). In addition, it minimizes farmers' risks by diversifying activities, hence permitting farmers to expand their marketing channels (Hendrickson et al., 2008).

\section{Cultural pradicos}

Agrochemical use is common among wheat farmers (92\% apply herbicides and $41 \%$ apply other pesticides). Agrochemicals, while applied to enhance crop yields and protect crops from pests, also increase the costs of food production and cause serious undesired side effects, including environmental contamination and health problems (Carvalho, 2006).

\footnotetext{
${ }^{3} \mathrm{E} x$ situ refers to the conservation of genetic resources off-site, such as in gene banks. In situ refers to the conservation of genetic resources in the wild and on farms, and it is often associated with traditional subsistence agriculture (Altieri \& Merrick, 1988).
} 
On the other hand, manure plays an important role in crop production and soil improvement. It promotes microbiological activities and phosphorus cycling in the soil, as well as reduces runoffs and decreases soil loss (Gilley \& Risse, 2000; Parham, D eng, Raun, \& Johnson, 2002). Yet only 5\% of surveyed wheat farmers apply manure.

All wheat farmers plow their fields, and some even practice excessive plowing. However, the notill agricultural approach has been proven very efficient in minimizing soil and crop residue disturbance, minimizing erosion losses, controlling soil evaporation, sequestering carbon in soil, and reducing energy needs (Lal, Reicosky, \& Hanson, 2007). Soil management is vital for the sustainability of production systems.

Among the drivers that affect production systems and cultural practices is knowledge. In Lebanon, farmers lack access to effective extension services (Q amar, 2012). Access to knowledge would be vital to reducing the application of agrochemicals and promoting organic farming, both of which would be promising for environmental and public health. Knowledge management and sharing as well as adequate extension services in Lebanon can effectively enhance the efficiencies of the farmers' agricultural production systems and sustain local wheat production.

\section{Socio-E onomic Sustainability}

\section{$\mathrm{L}$ and tenure systems}

Land tenure plays a vital role in farmers' livelihoods and livelihood strategies because the size of holdings shapes resource use and its allocative efficiency. O wnership additionally shapes land-based power in the society, the distribution of material wealth and income, and the right to transfer property (Sadr, 1972).

Land tenure systems in Lebanon have not benefitted the majority of farmers since 19th-century Ottoman rule, followed by the French mandatory powers. Since then, collective ownership was suppressed, often at the behest of real estate interests. This then facilitated mortgage lending by marketing the land and making it a real commercial commodity that is officially sold and licensed, hence allowing individuals and foreign companies to freely trade land. As soon as the collective types of ownership and semi-nomadic farms vanished, cultivators were exposed to excessive risks and resorted to borrowing, in which they lacked any guarantee or security of tenure (D aher, 1974; Sadr, 1972). In addition, as governments invariably aim to ensure participation of agriculture in the global trade and economy, the result has been the concentration of land ownership with national or foreign capital in the most productive areas. These areas are subject to more mechanized, irrigated, and specialized forms of production, open to long value chains, and driven by exports and large-scale distribution. This has resulted in further fragmentation of smaller holdings and the emergence of landless farmers (Bush, 2016). Today, big landowners, representing only $2 \%$ of this sector, control over $30 \%$ of agricultural land. However, small farmers, who represent over 95\%, occupy only half the agricultural area (Zurayk, 2012a). This is reflected in the current study, where only $24 \%$ of surveyed farmers own land. In addition, tenants, lacking security over land, are more likely to adopt monoculture production (85\% of surveyed tenants produce wheat on all their land) while owners, representing $16 \%$ of producers, tend to grow integrated wheat with other perennial crops (see Table 1). Offering farmers guarantee over land tenure would permit them to invest in sustainable production systems.

\section{Marketing}

The GD CS in Lebanon purchases wheat produced by local farmers at a guaranteed price and sells it at international market prices to the 13 mills operating in the country (Ministry of Finance $[\mathrm{MoF}]$ \& United Nations D evelopment Programme [UND P], 2012). However, as this study reveals, not all farmers sell their wheat to the directorate, despite the encouraging prices, and prefer to sell directly in the market to avoid the bureaucratic procedures and delay in payments by the government. Therefore, poor farmers who lack capital and cannot sustain themselves without relying on immediate cash do not have many marketing choices other than selling at low prices to dealers or traders who end up receiving the highest share of production.

Moreover, farmers are not organized in 
cooperatives; the farming sector in Lebanon lacks substantial cooperatives (Markou \& Starvi, 2005). This prevents farmers from gaining leverage in purchasing inputs and marketing their products. Cooperatives can play a vital role in supporting farmers' production and marketing strategies.

\section{Socio-eonomic factors}

Farming as a profession has become dominated by the aging; farmers around the world are aged between 50 to 60 years old on average (G lobal Forum on Agricultural Research [GFAR], 2016). This was reflected in this study, where $90 \%$ of surveyed wheat farmers are above 40 years old. Farming needs a change in image to attract young people. Y oung people must understand the value of farming and must be encouraged to become the future of agriculture (GFAR, 2016; VargasLundius, 2011).

Disguised under the façade of food security and modernization, policies undertaken in the MENA region in general have tended to ignore local rural conditions of poor people, especially farmers, landless people, and females, hence challenging rural well-being. Moreover, farmers' voices have always been absent from the family farming debate and the policies shaping agriculture and food security (Bush, 2016). In addition, protecting local agricultural production in Lebanon through quotas, tariffs, licensing procedures, etc., has been restrained because of Lebanon's participation in all international treaties and organizations advocating free trade (Markou \& Starvi, 2005). Lebanese farmers as a result have been trapped in poverty.

The Lebanese government has been trying to promote farmers' activities by subsidizing loans and subsidizing specific agricultural products such as wheat. The extent of wheat producers' dependence on government subsidies is affected by international markets and climatic conditions. In 2007 and 2008, for instance, when the price of wheat on the international market was high enough that the farmers sold their entire production directly to the market, no subsidy was made by the treasury to the General Directorate of Cereal and Sugar Beet (GDCS) (MoF \& UNDP, 2012) leading to a decrease in the number of farmers who benefited. However, in 2010, poor climatic conditions and floods affecting wheat yields, especially in the Bekaa region, were a major factor in decreasing the national wheat production. This put farmers in more need of government support than ever. Therefore, government support is vital, especially since wheat is a sensitive product, highly affected by international markets and climate change. The importance of government support for the sustainability of wheat production is revealed in this study, where only $8.5 \%$ of the producers said they would continue growing wheat if the government were to refrain from subsidizing wheat production.

However, such subsidies are not enough to secure farmers' livelihoods and sustain the Lebanese farming sector. This is clearly reflected in the current study by the large number of farmers specializing in agriculture, complemented by a large number of their family members involved in offfarm activities (Table 3). Wheat production in particular, and the agricultural sector in general, are under threat in Lebanon; ensuring their sustainability requires action.

Promoting farmers - especially the poorest small-scale producers who face extensive threats and are trapped in poverty-is a prerequisite for ensuring agricultural sustainability. Farming in Lebanon could be supported by targeted policies addressing small producers, farmers, workers, and local society. The laissez-faire economy of Lebanon, which has been deployed since the independence. has been shaping agrarian change and imposing serious challenges to farmers, and has been exacerbated by the lack of policies securing their livelihood strategies (Zurayk, 2012a). Farmers would benefit greatly from policies focusing on (1) access to resources; (2) organization of the farming sector, allowing farmers to gain a substantial portion of added value; and (3) collective organization of small-scale family farmers through associations, cooperatives, and informal groups. Together these policies would support the farmers' access to economies of scale for some of their activities as well as their participation in social and political dialogue (Bush, 2016). In addition, enhancing the social policies would offer small-scale farmers more security and empowerment. Such policies would include protecting farmers, including the right to retirement for old farmers (both men and women) and 
their access to quality education and healthcare, as well as provision for value systems (e.g., child labor, gender equality, access to cultural services). Regional rural development policies including the emergence of secondary towns, roads, social and cultural infrastructure in rural areas, and safety for people and property would also promote rural and cultural sustainability.

\section{By-products of W heat}

Among the surveyed wheat producers from the West Bekaa, 49\% process their wheat into either kishk alone, bulgur alone, or both kishk and bulgur. Bulgur and kishk are produced mainly for home consumption, which indicates that these production chains can, or are, playing a role in food security and income-generating activities. These products are traditional food reflecting culture and history, but their conservation has been threatened by commercially produced products (Chedid, Tawk, Chalak, Karam, \& Hamadeh, 2018). Chedid et al. (2018) investigate the production chain of traditional kishk in the West Bekaa, revealing that kishk production has not been affected by the changes that have occurred in the wheat sector, including the introduction of new wheat varieties. Replacing the traditional wheat landraces with improved hybrid varieties might deprive these traditional products of their original identity and added value. Theus wheat sustainability is essential for sustaining Lebanese culinary heritage. More attention should be given to the analysis and conservation of these traditional foods.

\section{Sustainability of W heat Production}

Agricultural production, especially of cereals, faces significant constraints in the MENA region (Al Masah Capital Limited, 2012) due to a shortage of arable land (less than 4\%) and water, and unfavorable weather conditions in many countries. MENA is considered one of the most water-scarce regions in the world, having an average water availability of $1,200 \mathrm{~m}^{3}\left(42,400 \mathrm{ft}^{3}\right) /$ person/ year in comparison to a global average of about 7,000 to $10,000 \mathrm{~m}^{3}$ $\left(247,000 \mathrm{ft}^{3}\right.$ to $\left.353,000 \mathrm{ft}^{3}\right) /$ person/ year (Siddiqui \& Anandon, 2011; World Bank, 2006). In addition, the regional average is estimated to drop to about $500 \mathrm{~m}^{3}\left(17,700 \mathrm{ft}^{3}\right.$ ) per person by 2025 (Siddiqui \&
Anandon, 2011). In Central and West Bekaa, 50\% of the planted wheat area is irrigated. Farmers usually irrigate wheat 2 to 3 times per season to supplement rain shortage during the spring (A prilMay). In 2005, 143,700 tons of wheat were produced on 49,500 ha (122,300 acres); this production increased to 150,000 tons (over 38,000 ha [93,900 acres] of land) in 2012 to dropped to 140,000 tons on 37,000 ha (91,400 acres) in 2013 (Ministry of Environment, 2011). Therefore, wheat yield did not change in relation to the cultivated land surface, as the highest yields of 2012 were not obtained from the largest surface, and the wheat productivity changed from $2.9 \mathrm{t} /$ ha $(1.2 \mathrm{t} /$ acre) to $3.95 \mathrm{t} /$ ha (1.6 t/ acre) to $3.58 \mathrm{t} /$ ha (1.45 t/ acre). Instead, this could be due to rain instability, supplemental irrigation, and even fluctuating temperatures (maxima and minima), as they seriously affect wheat yields. Therefore, the exacerbation of climate change, which is already felt and will be further felt in the future with increasing temperatures and fluctuating rainfalls, will influence wheat production in Lebanon and requires active strategies, focusing on mitigating water shortages, improving storage, diversifying the supply, and regulating usage (Ahmed et al., 2013).

In addition to their main role in promoting rural livelihoods, agricultural landscapes play a vital role as habitat for biodiversity and natural resources, especially landscapes managed by smallscale farmers promoting ecofriendly agricultural practices (Lockie \& Carpenter, 2010). However, agriculture in Lebanon is facing numerous economic, demographic, and climatic challenges, resulting in a loss of resources, structures, and assets. A high population growth rate- the highest in the region (6\%) - is imposing serious urbanization in Lebanon, thereby decreasing the limited agricultural land due to expanding cities (UN D ata, 2017)., Urban centers in Lebanon traditionally have been built strategically near water resources and fertile lands. But as the population expanded, more land was used for residential areas and less land has remained for farming (Zurayk, 2012a). In addition, considerable emigration has been occurring due to internal and external conflicts since the $19^{\text {th }}$ century, and rural-to-urban migration has been a strong social force within Lebanon. Peasants have 
moved to the cities to pursue improved living conditions or to escape the horrors of war and poverty (Abu Khalil, 1989). These demographic shifts have resulted in a reduction in farming and a transformation of the production patterns and agricultural and rural landscapes. Supporting farmers- especially small-scale farmers, who are the stewards of the land and natural resources- is important in order to sustain traditional farming practices and preserve the cultural landscapes. The Lebanese government, as well as the private sector (e.g., NGOs and research and development institutions), can play a vital role in this respect. Access to finance, markets, and knowledge must be promoted for wheat farmers to support the traditional production of wheat and its by-products.

In addition, food and landscape are very closely interrelated and represent the two sides of a heritage (Zurayk, 2012a; Zurayk, 2012b); if one of these two is subject to change, the second is affected. Concurrently, according to Muchnik and De Sainte Marie (2010), the landscape evolves with the diet and eating habits of people, and the demand for traditional and local food production can have a positive impact on landscape and agrobiodiversity. On the contrary, however, an increased demand for processed and imported food can have damaging effects on preserving landscape and agrobiodiversity. Therefore, in addition to supporting farmers, influencing consumers plays an important role in preserving wheat production and its traditional by-products.

\section{Conclusion and Recommendations}

Wheat is a staple grain in the Lebanese diet and the Levantine breadbasket. This study reveals that integrated production systems in West Bekaa are adopted by a considerable number of farmers, and such systems hold substantial potential for sustainability. Wheat production in particular, and the agricultural sector in general, are under serious threat. The important challenges faced by farmers are revealed in this study. Farmers in West Bekaa are highly dependent on improved wheat varieties and have abandoned landraces. They have been suffering from a lack of tenure security, where most wheat producers are tenants in a country characterized by a laissez-faire agricultural policy that constrains their agricultural development and innovation. In addition, they lack access to substantial cooperatives, hindering their marketing strategies. The future of wheat production in Lebanon is critically threatened since wheat farmers are an aging demographic and most wheat farmers rely on government subsidies. In order to promote the sustainability of wheat production in Lebanon, further investigation and research are needed to identify producers using landraces because conserving landraces is vital for retaining agrobiodiversity and promoting food security. In addition, wheat landraces are important for the sustainability of original identity and the added value of their by-products, kishk and bulgur. Being an essential raw material for different traditional products, sustaining wheat is crucial for sustaining Lebanese culinary heritage. Certification and quality control could play an important role in this respect, such as by urging producers to use wheat landraces in the production of these by-products. The promotion of cooperatives would result in organizing and linking farmers to producers, hence also increasing the demand for local wheat varieties.

More attention should be given to analyzing and conserving these traditional foods. Giving farmers the right incentives for planting and conserving wheat landraces from the Levant, where they originated, and preserving buffer zones for wild crop relatives holds significant potential in this respect. Knowledge management, knowledge sharing, and extension services could effectively promote sustainability in agriculture, and offering farmers security over land tenure would permit them to invest in sustainable production systems. Moreover, developing strong cooperatives would aid farmers in purchasing inputs and marketing their products. Spreading awareness of the benefits of local food systems and the challenges that wheat farmers face would encourage consumers to eat locally produced food. In addition, supporting Lebanese culinary heritage through tourism and other cultural activities would aid in sustaining traditional products, such as the traditional kishk and bulgur.

Threatened by climate change, wheat production sustainability requires specific strategies that focus on mitigating water shortages and improving 
its storage, supply diversification, and regulation. D eveloping policies to support farmers, their production, and their livelihoods holds great potential for sustaining the entire farming sector in general and wheat production in particular. In order to target such specific policies in a specific context, it would be very valuable and beneficial to conduct comprehensive studies and collect information on the diversity of small-scale family farms, their sources of income, their performance, and their livelihood strategies (Bush, 2016). The current study manifests a first step in assessing the state of wheat farmers in the West Bekaa. Further studies are recommended to encompass all wheat farmers across Lebanon.

\section{Acknowledgments}

We thank professor Samih el Haij for assisting in confirming the terminology of the wheat varieties, Dr. Suzy Roufael in defining in situ and ex situ conservation of landraces, and all members of the Environment and Sustainable D evelopment Unit at the American University of Beirut for their help with the survey.

\section{References}

Abu Khalil, A. (1989). The society and its environment. In T. Collelo (Ed.), L ebanon: A country study (pp. 41-86). Washington, DC: Library of Congress, Federal Research Division.

Ahmed, G., Hamrick, D ., Guinn, A., Abdulsamad, A., \& G ereffi, G. (2013). Wheat value chains and food security in the Middle East and North Africa region. D urham, North Carolina: Duke University, D uke Center on Globalization, G overnance and Competitiveness. Retrieved from https:/ / sites.duke.edu/ minerva/ files/ 2014/ 04/2013-0828 CGGC Report Wheat GVC and food security in MENA.pdf

Al Masah Capital Limited. (2012). M E N A food seaurity: A re we doing enough to feed the population? D ubai, UAE, Al Masah Capital Management Limited. Retrieved from http:/ / www.almasahcapital.com/ images/ reports/ report 20.pdf

Allen, P. (2010). Realizing justice in local food systems. C ambridge Journal of Regions, E conomy and Society, 3(2), 295-308. https:// doi.org/ 10.1093/ cjres/ rsq015

Altieri, M. A., \& Merrick, L. C. (1988). Agroecology and in situ conservation of native crop diversity in the Third World. In E. O. Wilson \& F. M. Peters (Eds.), Biodiversity (Chapter 41). Washington, D .C.: National Academies Press. Retrieved from https:// www.ncbi.nlm.nih.gov/ books/ NBK219289/

Anderson, S. (2003). Sustaining livelihoods through animal genetic resources. In CIP-UPWARD . C onservation and sustainable use of agricultural biodiversity. A source book (pp. 1-6). Los Banos, Philippines: International Potato CenterUsers Perspectives with Agricultural Research and D evelopment.

Assi, R. (2005). Project on "Conservation and sustainable use of dry land agrobiodiversity in the N ear E ast." United Nations Development Program (UNDP), G lobal Environment Facility (GEF), Lebanese Agricultural Research Institute (LARI), and International Center for Agricultural Research in Dry Areas (ICARD A). Final Report of the Lebanese Component.

Bar-Y osef, O ., \& Belfer-Cohen, A. (1989). The origins of sedentism and farming communities in the Levant. Journal of W orld Prehistory, 3(4), 447-498. https:// doi.org/ 10.1007/ BF00975111

Blominvest Bank. (2016, May 13). The L ebanese wheat mark et: A lay of the land. Retrieved from http:/ / blog.blominvestbank.com/ wp-content/ uploads/ 2016/ 05/ The-Lebanese-Wheat-Market-A-Lay-of-theLand1.pdf

Boller, E. F., Avilla, J., Joerg, E., Malavolta, C., Wijnands, F. G ., \& Esbjerg, P. (2004). Integrated production: Principles and technical guidelines ( $3^{\text {rd }}$ ed.). D ijon, France: International Organisation for Biological and Integrated Control/ West Palearctic Regional Section Bulletin, 27(2). Retrieved from https:// www.iobc-wprs.org/ ip ipm/archive/ iobc bas.pdf

Bush, R.C. (2016). F amily farming in the N ear E ast and N orth A frica (Working Paper No. 151). Brasilia: International Policy Centre for Inclusive G rowth, United Nations D evelopment Programme, and Food and Agriculture O rganization of the United Nations.

Camacho Villa, T. C., Maxted, N., Scholten, M., \& Ford-Lloyd, B. (2005). D efining and identifying crop landraces. Plant G enetic Resources, 3(3), 373-384. https:/ / doi.org/ 10.1079/ PG R200591 
Journal of Agriculture, Food Systems, and Community Development

ISSN: 2152-0801 online

https:/ / www.foodsystemsjournal.org

Caraher, M., Dixon, P., Lang, T., \& Carr-Hill, R. (1999). The state of cooking in England: The relationship of cooking skills to food choice. British F ood Journal, 101(8), 590-609. https:/ / doi.org/ 10.1108/ 00070709910288289

Carvalho, F. P. (2006). Agriculture, pesticides, food security and food safety. E nvironmental Scienœ \& Policy, 9(7-8), 685692. https:/ / doi.org/ 10.1016/ j.envsci.2006.08.002

Chalak, L., \& Sabra, N. (Eds.). (2015). Lebanon: Second report on the state of plant genetic resources for food and agriculture. Retrieved from http:/ / www.fao.org/ pgrfa-gpa-archive/ lbn/ lebanon2.pdf

Chedid, M., Tohmé Tawk, S., Chalak, A., Karam, S., \& Hamadeh, S. (2018). The Lebanese kishk: A traditional dairy product in a changing local food system. Journal of F ood Research, 7(5), 16-23. https:/ / doi.org/ 10.5539/ jfr.v7n5p16

Daher, M. (1974). T arikh L ubnan al litimai i 1914-1926. [T he Social H istory of L ebanon 1914-1926]. Beirut: Al Shrgiyya Publishers.

Esquinas-Alcázar, J. (2005). Protecting crop genetic diversity for food security: Political, ethical and technical challenges. N ature Reviews G enetics, 6(12), 946-953. https:/ / doi.org/ 10.1038/ nrg1729

Fisher, A. (1997). What is community food security? U rban E cologist, 2, 3-4.

Follieri, M. (1973). Cereali del villaggio neolitico di Passo di Corvo (Foggia) [Cereals from the Neolithic village of Passo di Corvo (Foggia)]. A nnali di Botanica, 32, 49-61.

Food and Agriculture O rganization of the United Nations [FAO ]. (2008). Climate change and biodiversity for food and agriculture (D ocument No. HLC/ 08/ BAK/ 3). FAO, Rome. Retrieved from http:/ / www.fao.org/ uploads/media/ FAO_2008a_climate_change_and biodiversity_02.pdf

Gilley, J. E., \& Risse, L. M. (2000). Runoff and soil loss as affected by the application of manure. Transadions of the A merican Society of A gricultural E ngineers, 43(6), 1583-1588. https:/ / doi.org/ 10.13031/ 2013.3058

Global Forum on Agricultural Research [GFAR]. (2016). Farming makeover needed to attract youth. Retrieved from http:/ / www.gfar.net/ news/ farming-makeover-needed-attract-youth

Gottlieb, R., \& Joseph, H. (1997, O ctober). Building toward the millennium: U nderstanding the past and envisioning the future of the Community F ood Security Coalition. Discussion paper distributed at First National Community Food Security Conference, Los Angeles, California.

Grain. (1996). Ex situ conservation: When the fridge breaks down. Seedling. Retrieved from https:/ / www.grain.org/ es/ article/ entries/ 330-ex-situ-conservation-when-the-fridge-breaks-down

Guarino, L., \& Lobell, D.B. (2011). A walk on the wild side. N ature Climate Change, 1, 374-375. https:/ / doi.org/ 10.1038/ nclimate1272

Harrigan, J. (2014). An economic analysis of national food sovereignty policies in the Middle East: The case of Lebanon and Jordan. In Z. Babar \& S. Mirgani (Eds.), F ood security in the M iddle E ast (Chapter 3). Oxford, UK: Oxford University Press. https:// doi.org/ 10.1093/ acprof:oso/ 9780199361786.003.0003

Hellin, J., \& Meijer, M. (2006). G uideline for value chain analysis. G eneva: Food and Agriculture O rganization of the United Nations [FAO ]. Retrieved from http:// www.fao.org/3/a-bq787e.pdf

Hendrickson, J. R., Hanson, J. D ., Tanaka, D . L., \& Sassenrath, G . (2008). Principles of integrated agricultural systems: Introduction to processes and definition. Renewable A griculture and F ood Systems, 23(4), 265-271. https:/ / doi.org/ 10.1017/ S1742170507001718

Kislev, M. E. (1984). Emergence of wheat agriculture. Paléorient, 10(2), 61- 70. https:/ / doi.org/ 10.3406/ paleo.1984.940

Lal, R., Reicosky, D. C., \& Hanson, J. D . (2007). Evolution of the plow over 10,000 years and the rationale for no-till farming. Soil and Tillage Research, 93(1), 1-12. https:// doi.org/ 10.1016/ j.still.2006.11.004

Lebanese Agriculture Research Institute (LARI) \& Republic of Lebanon Ministry of Agriculture [MoA]. (2014). W heat altivation in L ebanon [in Arabic].

Lockie, S., \& Carpenter, D. (Eds.). (2010). A griaulture, biodiversity and mark ets: L ivelihoods and agroecology in comparative perspective. London: Routledge.

Madry, W., Mena, Y., Roszkowska-Madra, B., G ozdowski, D ., Hryniewski, R. \& Castel, J. M. (2013). An overview of farming system typology methodologies and its use in the study of pasture-based farming system: A review. Spanish Journal of A griaultural Research, 11(2), 316-326. https:/ / doi.org/ 10.5424/ sjar/ 2013112-3295

Markou, M., \& Stavri, G . (2005). N ational agricultural policy report L ebanon. Cyprus: Agricultural Research Institute. Retrieved from http:// www.databank.com.lb/ docs/ National\%20Agricultural\%20Policy\%20Report.pdf 
Maxted, N., Ford-Lloyd, B. V., Jury, S., Kell, S., \& Scholten, M. (2006). Towards a definition of a crop wild relative. Biodiversity \& Conservation, 15(8), 2673-2685. https:/ / doi.org/ 10.1007/ s10531-005-5409-6

McCorriston, J., \& Hole, F. (1991). The ecology of seasonal stress and the origins of agriculture in the Near East. A merican A nthropologist, 93(1), 46-69. https:/ / doi.org/ 10.1525/ aa.1991.93.1.02a00030

Muchnik, J., \& De Sainte Marie, C., (Eds). (2010). L e temps des SY A L (Systèmes A groalimentaires L ocalisés): T echniques, vivres et territoires [The time of the localized food systems : Techniques, food, and land]. Versailles, France: Editions Quæ. Update Science \& Technologies. https:/ / doi.org/ 10.3917/ quae.muchn.2010.01

Nigatu, G., \& Motamed, M. (2015). Middle E ast and N orth A fric region: A n important driver of world agricultural trade (Report AES-88). U.S. D epartment of Agriculture, Economic Research Service. Retrieved from https:/ / permanent.access.gpo.gov/ gpo64990/ aes88.pdf

O hlsson, T. (2014). Sustainability and food production. In Y. Motarjemi \& H. Lelieveld (Eds.), Food safety management: A practical guide for the food industry (pp. 1085-1097). London: Elsevier. https:/ / doi.org/ 10.1016/ B978-0-12-381504-0.00043-3

Parham, J., D eng, S., Raun, W., \& Johnson, G . (2002). Long-term cattle manure application in soil. Biology and F ertility of Soils, 35(5), 328-337. https:/ / doi.org/ 10.1007/ s00374-002-0476-2

Qamar, K. (2012). Lebanon. Global Forum for Rural Advisory Services. Retrieved from https:/ / www.g-fras.org/ en/ knowledge/ extension-training-directory/ 130-world-wide-extensionstudy/ asia/ western-asia/ 309-lebanon.html\#resources

Quitta H. (1971). D er Balkan als Mittler zwischen Vorderem O rient und Europa. In F. Schlette (Ed.), E volution und Revolution im A lien Orient und in E uropa (pp. 38-63). Berlin: Akademie Verlag.

Republic of Lebanon Ministry of Agriculture [MoA], Food and Agriculture Organization of the United Nations [FAO ], \& Italian Ministry of Foreign Affairs. (2012). Résultats globaux du module de base du Recensement de l'agriculture. Projet "O bservatoire Libanais de D éveloppement Agricole" [O verall results of the basic module of the Census of agriculture. Project "Lebanese O bservatory of Agriculture D evelopment"]. Beirut, Lebanon.

Republic of Lebanon Ministry of Environment \& United Nations D evelopment Programme [UNDP]. (2011). Lebanon's second national communication to the United Nations Framework Convention on Climate Change. Retrieved from http:/ / climatechange.moe.gov.lb/ viewfile.aspx?id=19

Republic of Lebanon Ministry of Finance [MoF] \& UNDP. (2012). W heat and bread subsidies 2007-2011. Ministry of Finance Thematic Reports. Retrieved from http:/ / www.finance.gov.lb/ en-us/ Finance/ Rep-Pub/ D RIMOF/ Thematic\%20Reports/ / Thematic\%20Report\%20Wheat\%20subsidy\%20Final\%202.pdf

Sadr, S.K. (1972). L and tenure in L ebanon (D octoral dissertation). American University of Beirut.

Sassenrath, G. F., Hanson, J. D ., Hendrickson, J. R., Archer, D. W., Halloran, J. M., \& Steiner, J. J. (2009). Principles of dynamic integrated agricultural systems: Lessons learned from an examination of Southeast production systems. In P. Bohlen \& G. House (Eds.), Sustainable agro-ecosystem management: Integrating eoology, economics, and society (pp. 259-269). Boca Raton, Florida: CRC Press.

Siddiqi, A., \& Anadon, L. D . (2011). The water-energy nexus in Middle East and North Africa. E nergy policy, 39 (8), 45294540. https:/ / doi.org/ 10.1016/ j.enpol.2011.04.023

Tohmé Tawk, S., Abi Said, M., \& Hamadeh, S. (2014). Urban agriculture and food security in the Middle Eastern context: A case study from Lebanon and Jordan. In Z. Babar \& S. Mirgani (Eds.), Food security in the MiddleE ast (pp. 161-186). Oxford, UK: Oxford University Press. https:/ / doi.org/ 10.1093/ acprof:0so/ 9780199361786.003.0007

Tohmé Tawk S., Moussa Z., Hamadeh S., \& Abi Saiid, D . (2011). D eveloping value chains in Amman, Jordan. U rban A griculture Magazine, 25, 54-56. Retrieved from https:/ / www.ruaf.org/ developing-value-chains-amman-jordan

UN D ata. (2017). L ebanon. United Nations Statistics D ivision. Retrieved from http:/ / data.un.org/ en/ iso/ lb.html

Vargas-Lundius, R. (2011). Feeding future generations: Young rural people today- prosperous, productive farmers tomorrow. Proceedings of the G overning Council High-Level Panel and Side Events, International Fund for Agricultural Development [IFAD ].

Vollbrecht, E., \& Sigmon, B. (2005). Amazing grass: D evelopmental genetics of maize domestication. Biochemical Society Transactions, 33(6), 1502-1506. https:/ / doi.org/ 10.1042/ BST0331502 
Walters, J. P., Archer, D. W., Sassenrath, G. F., Hendrickson, J. R., Hanson, J. D ., Halloran, J. M., ... Alarcon, V. J. (2016). Exploring agricultural production systems and their fundamental components with system dynamics modelling. E cological M odelling, 333, 51-65. https:/ / doi.org/ 10.1016/ j.ecolmodel.2016.04.015

World Bank. (2006). W ater resourœ management in M ena. Washington, D .C.: World Bank. Retrieved from http:// siteresources.worldbank.org/ INTMNAREGTOPWATRES/ Resources/WATER-ENG.pdf

World Bank, FAO \& \& International Fund for Agricultural D evelopment. (2009). Improving food searity in A rab countries. Washington, D.C.: World Bank. Retrieved from http:/ / documents.worldbank.org/ curated/ en/ 733841468026409174/ pdf/ 512170WP0food110Box342021B01PUB LIC1.pdf

Zahm, F., Viaux, P., Vilain, L., G irardin, P., \& Mouchet, C. (2008). Assessing farm sustainability with the IDEA method - From the concept of agriculture sustainability to case studies on farms. Sustainable D evelopment, 16(4), 271-281. https:// doi.org/ 10.1002/ sd.380

Zurayk, R. (2012a, January 10). Agriculture and land tenure in Lebanon: Will anyone dare challenge the big landowners? [Blog post]. Retrieved from http:/ / landandpeople.blogspot.com/ 2012/ 01/ agriculture-and-land-tenure-inlebanon.html

Zurayk, R. (2012b). Can sustainable consumption protect the Mediterranean landscape? In CIHEAM (Ed.), M ediTE R RA 2012: The M editerranean diet for sustainable regional development (pp. 155-170). Paris: Presses de Sciences Po. Retrieved from https:// www.cairn.info/ mediterra-2012-english--9782724612486-page-155.htm 